Government, as they affect citizens, around seven central themes. One, for example, displays in dramatic form what Uncle Sam does for Mr. Average Man from birth through old age-how, for example, Public Health Service grants provide better maternity care and how the Social Security Board now provides for a man in his declining years.

Indians demonstrate their handicrafts in the Federal building. Not only do they show their unique art, but also they may start a vogue for Indian handicrafts among visitors. Planners of the exhibit certainly hope so, for such a boom would prove a boon to the Rəd man, who has not had an easy row to hoe in adapting himself to the white man's civilization.

Chemical wizardry, as practised by industrial giants whose ever-new products enter into everyone's life every day, are also shown. The Dow Chemical Company shows how it makes ocean water yield up magnesium, the lightest metal now in use, and iodine and bromine, two vital chemicals which enter into, among other things, the old stand-by antiseptic and photographic film respectively.

A chemist pours the clear contents of one beaker into another and a gummy substance, which is then moulded into proper shape, results. It is allowed to solidify, and, lo! a rubber tyre. How chemistry makes for better living in this and in other ways is shown by E. I. du Pont de Nemours and Co.

An 'iron lung', about which much has been heard recently and which has saved many lives, is there. Visitors have a chance to watch one at work in a model hospital erected by Dr. Gabriel Barnett.

In charge of the vast science programme in the Hall of Science alone has been Dr. Milton Silverman. Co-operating with him as exhibitors he has had some of the foremost scientific institutions in the United States. Harvard University, the Mayo Clinic, the Jackson Clinic and the American Medical Association, to mention only a few, are taking part. More than two hundred and fifty industrial exhibits, of which many are science shows all by themselves, are represented.

\title{
Technical Education in Great Britain
}

$\mathrm{A}^{\mathrm{s}}$ $\mathrm{S}$ was to be expected, the principal discussion at the annual meeting, held in London on February 24-25, of the Association of Technical Institutions, centred around the recommendations with regard to technical education put forward in the Spens Report. Sir Henry Steward, chairman of the City and Guilds of London Institute, who has succeeded Sir Robert Pickard as chairman of the Association, presided over the meetings, which were held in the Hall of the Merchant Taylors Company.

The discussion was opened by Principal J. Paley Yorke, one of the signatories to the Report, and chairman of the Council of the Association. He said that the general trend of the Report has been aptly expressed by one commentator as "a shifting of the basis of education from one of social habit to one of natural aptitude". Who should say that a parent should not take account of the social implications which attach themselves to a child by attendance at one school or another ? But if some equality of status can be secured between schools of different educational types the parent will no longer find himself forced to weigh social esteem against educational provision. $\mathrm{He}$ need only think of the fitness of the curriculum for the aptitude and the inclinations of the child. The text of the Report on the inside title-page is "Chacun doit être à portée de recevoir l'éducation qui lui est propre." The recommendations endeavour to make that possible.
Mr. Paley Yorke then went on to describe and explain the findings of the Committee set out in Chapter viii--"Technical High Schools and other Technical Schools". He pointed out that the terms of reference made it necessary for the Committee to give a detailed consideration of the aims, objects and work of those schools called Junior Technical Schools and to determine their actual and potential relation to secondary schools of other types. This is the first time in history that so complete an examination has been made by so important a Committee. The members of the Committee found it necessary to collect a large body of evidence, and they visited a number of representative schools to obtain for themselves a true picture of their work, of the staffing, equipment and corporate life. The Committee was greatly impressed through these visits and was the better able to assess the oral and written evidence received. It recognized that there are two main groups of Junior Technical Schools in existence-one frankly and definitely preparing its pupils for entry into a specific occupation and developing in them a substantial measure of personal skill in the processes of that occupation-the other providing an educational foundation and background with science and its applications as the core and inspiration of the curriculum for those whose broad intention it is to enter industry without reference to any particular occupation within it. It came to the very definite conclusion that the schools of this second 
group are capable of developing, and indeed already had developed in a large degree, a form of secondary education which ought to be regarded as an alternative to that of a Grammar School.

From this the Committee made its now famous recommendation that a new type of school should be established to be called a Technical High School - to be accorded in every respect equality of status with schools of the Grammar School type, yet to be wholly distinct from them. As a first step it was recommended that a number of these Junior Technical Schools at present providing a curriculum based on the engineering and building industries should be converted into Technical High Schools. The recommendation carried with it the provision of a minimum course of five years with a recruitment at 11 plus years, the recruitment based on the method of the general selective examination by which children are recruited for the Grammar Schools, the ultimate selection being determined in accordance with the choice of the parents, the report of the head of the contributing school and the result of interviews.

It was considered essential, of course, that the curriculum of the 11 plus to 13 plus pupils should be broadly of the same character as that in other secondary schools so that there could be another age point, in all schools, namely 13 plus, at which transfers should, if desirable, be made-equally for eliminating misfits, and for the encouraging of aptitudes which might have emerged and for allowing a change of choice on the part of the parents.

Several points emerged from the recommendations, and Mr. Paley Yorke made special reference to the question of the housing and staffing of the Technical High Schools, because he feels that there has been much misunderstanding about it and much non-understanding criticism from established secondary school quarters.

The Consultative Committee had no doubt whatever that the special value of the Technical High School depends upon its contact with the equipment and with the staff of a Technical College. The examples were before it. The evidence was there. The experiment has been conducted for more than thirty years with the 13 plus to 16 plus group, and there is no doubt at all about the results. Therefore it said that where possible Technical High Schools should be housed in the Technical Colleges and Technical Institutes and should be a department of the College, and the head master of the School would be head of that department. It is recognized, however, that the discipline, the corporate life and the general conduct of the school are necessarily distinct from those of the College, and that for these the head master should be responsible. It is also considered an essential feature of the 'Technical High School that it should have some use of some of both the equipment and the staff of the College. Thus the head master of the School will have certain staff units wholly under his direction and will also have other members of the college staff working for him for a portion of their time, but who are not full-time members of the school staff. These teaching units will be attached to the College under the direction of one or other of the several heads of the departments of the College.

This organization of a Technical College into departments is not known in the secondary school world-and that accounts for the non-understanding of the essential condition that the principal of the College must secure and maintain the cooperation of the several heads of the specialized departments and their staffs, and the use of the laboratories, shops and special equipment, in the work and the life of the school.

There need be no fears about all this. It has been in operation for years and it is completely successful. The Committee is satisfied that-provided that a sub-committee of the Governing Body be appointed to manage the school and the head master has direct access to it, and the appointment of staff engaged exclusively in the work of the school be made in consultation with him-the organization of a Technical College through its principal and heads of departments allows a sufficient measure of autonomy to the head masters of the Technical High Schools whilst securing that vital contact of the School with the staff and equipment of the College which it regards as of primary importance.

Finally, in his review, Mr. Paley Yorke dealt with the vitally important recommendation of a form of school-leaving certificate based on internal examinations-assessed by approved assessors and endorsed by the Board of Education. As a body, the Association is familiar with certificates of this form through the now well-known and highly successful National Certificates and Diplomas. He is glad indeed that the Committee had been able to state so clearly that it does not seek to impose upon the Technical High Schools any system of external examination, with the necessarily rigid syllabus which would inevitably follow in its wake.

In the course of the subsequent discussion-a discussion which was carried over to the next morning-criticism came from those interested in education for commerce that the Committee has not recommended the establishment of Technical High Schools with a curriculum based on commercial education. Mr. Paley Yorke replied that the Committee had taken the view that, as at present constituted, the Junior Commercial Schools recruiting at 13 plus and 14 plus are more directly 
comparable with those Junior Technical Schools preparing their pupils for entry to a specific occupation. Their usefulness and functions are not denied. He pointed out that this decision was based on the evidence received, but that though the door has at present been closed against their becoming Technical High Schools, it has not been locked or bolted; and indeed might be said to be slightly ajar. In reply to other points raised, he pointed out that it was recommended that the word 'Junior' should be discontinued and that the official designation should be Technical Schools for the two and three-year course schools and Technical High Schools for the others; but it was also recommended that each school should have its own local name.

\section{Obituary Notices}

\section{Prof. Karl Schröter}

$\mathrm{T}$ HE nestor of Swiss botanists, Karl Schröter, emeritus professor in the Federal College of Technology, Zurich, died on February 7 in his eighty-fourth year. Up to the last he was physically and mentally active, and so recently as January 28 he delivered a public lecture to a leading scientific society in Zurich. Unfortunately, after a brief attack of pneumonia following upon influenza, his long and active life came to a sudden end.

Karl Schröter was born in 1855 in Esslingen in Germany, where his father was then chief engineer in a large engineering establishment, but later appointed professor of engineering in the Federal College of Technology, Zurich. At this institution, his son Karl, who acquired Swiss nationality, commenced his studies of natural science and came under the stimulating influence of Karl Cramer, who persuaded him to devote himself to the study of botany. Two years after graduation in 1876, he established himself as Privat Dozent and a few years later he was invited to give a course of advanced lectures in place of Prof. Heer, who was taken seriously ill. He proved himself to be such a successful lecturer that on the death of Prof. Heer he was appointed, at the age of twenty-eight years, to the vacant professorship, which he held for forty-two years.

Schröter had been influenced in his botanical studies by his predecessor, choosing for his doctor's thesis the examination of some fossil woods collected by Heer in the far north.

Schröter was, however, more interested in living plants, and as an assistant he took an active part in the organization of botanical excursions for the students, by which means he acquired a very wide and varied acquaintance with the Swiss flora, which characterized his later work both as a teacher and as an investigator. In 1889 , he published a pocket-flora of alpine plants which was translated into both French and English. He was, however, specially interested in the relationship of plants to their surroundings, and thus was one of the founders of the modern study of ecological botany. After many years work on alpine meadows and moorlands, he published, with the assistance of other botanists, in six parts during the years 1904-8 his "Plant-life in the AIps", a very comprehensive study of alpine vegetation. At the same time, he was collaborating with J. Früh in the production of a monumental volume on the bogs of Switzerland. He did not, however, confine himself to flowering plants, but paid attention to the plankton flora of the Swiss lakes and published several accounts of the periodicity of some of its algal forms.

In 1898, Schröter undertook a journey around the world, visiting the United States, Honolulu, Japan and Java. The result of his trip made him an enthusiastic supporter of the movement to organize international phytogeographical excursions, and in connexion with these he visited both Great Britain and the United States. Though already ageing in 1923, he organized and led a party of plant geographers through the Swiss Alps. By that time, the Swiss National Park had been established in the Lower Engadine, and Schröter, who had been keenly interested and active in its establishment and had taken part in its botanical exploration, naturally included it in the itinerary of the excursion.

Schöter's many-sided botanical labours received due recognition both in Switzerland and abroad. $\mathrm{He}$ was elected a foreign member of the Linnean Society of London in 1925 and delivered the Hooker Lecture of the Society in 1926. His lively and charming personality gained him many friends at home and abroad, not a few in England, which he visited on several occasions.

He married in 1884 a fellow student, Margaret Middelberg of Amsterdam, who died in 1925. Five years later he married Mrs. Teterode, by whom he is survived.

F. E. WEISS.

\section{Prof. J. Versluys}

THE death is announced, at the age of sixty-six years, of the eminent Dutch zoologist, Prof. Jan Versluys, professor in the University of Vienna.

Versluys was a fine, tall man, with a fluent command of English, German and French, and was well known to, and highly respected by, many British zoologists who met him either abroad or in Great Britain on the occasions when he attended the meetings of the British Association. He was a pupil of his life-long friend the late Prof. Max Weber of Amsterdam.

As a young man, Versluys accompanied Max Weber as a naturalist on the memorable voyage of S.S. Siboga on its marine exploration of the seas of the Malay Archipelago during 1899-1900, and on 